\title{
Efikasi Fortifikasi Cookies Ubi Jalar untuk Perbaikan Status Anemia Siswi Sekolah
}

\author{
Dodik Briawan, ${ }^{1,2}$ Aris Sulaeman, ${ }^{2}$ Elvira Syamsir, ${ }^{1,3}$ Dian Herawati ${ }^{1,3}$ \\ ${ }^{1}$ Seafast Center-LPPM-IPB, ${ }^{2}$ Departemen Gizi Masyarakat-FEMA-IPB, ${ }^{3}$ Departemen Ilmu dan \\ Teknologi Pangan-FATETA-IPB
}

\begin{abstract}
Abstrak
Selain suplementasi tablet besi, fortifikasi pangan lokal diperlukan sebagai alternatif program untuk perbaikan status besi. Tujuan penelitian ialah menguji efikasi fortififikasi cookies ubi jalar untuk peningkatan hemoglobin (Hb) pada siswi sekolah. Studi dilakukan dengan desain pre-post intervention study, yang melibatkan 74 siswi SMK Pelita Kabupaten Bogor. Studi dilaksanakan pada bulan Mei-Juli 2012. Cookies ubi jalar difortifikasi dengan 10,5 $\mathrm{mg}$ vitamin A, $42 \mu \mathrm{g}$ vitamin B12, 1,25 g vitamin C, $2 \mathrm{mg}$ asam folat, dan besi fumarat $150 \mathrm{mg}$ per $100 \mathrm{~g}$. Cookies sebanyak $40 \mathrm{~g}$ diberikan seminggu tiga kali selama dua bulan. Hasil penelitian menunjukkan kadar Hb rata-rata sebelum intervensi 13,4 $\pm 1,4 \mathrm{~g} / \mathrm{dL}$. Setelah intervensi, terdapat perubahan kadar $\mathrm{Hb} 0,4 \pm 1,6 \mathrm{~g} / \mathrm{dL}$ dan sebanyak $65,2 \%$ subjek mengalami kenaikan $\mathrm{Hb}$. Kenaikan $\mathrm{Hb}$ ini tidak memengaruhi prevalensi anemia yang sedikit meningkat dari $10,8 \%$ menjadi $18,8 \%$ dan secara statistik tidak nyata $(\mathrm{p}>0,05)$. Simpulan, intervensi fortifikasi cookies ubi jalar selama dua bulan tidak menurunkan prevalensi anemia pada anak sekolah. Disarankan studi berikutnya untuk menambah waktu intervensi dan menggunakan indikator status besi lainnya. [MKB. 2013;45(4):206-12]
\end{abstract}

Kata kunci: Anemia, cookies, fortifikasi, siswi, ubi jalar

\section{Efficacy of Fortified Sweet Potato Cookies for Improving Anemia Status in Female Students}

\begin{abstract}
Local food fortification for improving iron status is one of the alternative programs in addition to iron tablet supplementation. The objective of this study was to analyze the efficacy of fortified sweet potato cookies for improving hemoglobin $(\mathrm{Hb})$ concentrations in female students. The pre-post intervention study was applied to 74 female students of SMK Pelita in Bogor District. The study was conducted from May to July 2012. The sweet potato cookies used were fortified with $10.5 \mathrm{mg}$ vitamin A, $42 \mu \mathrm{g}$ vitamin B12, $1.25 \mathrm{~g}$ vitamin C, $2 \mathrm{mg}$ folic acid, and $150 \mathrm{mg}$ iron fumarate per $100 \mathrm{~g}$ cookies. Subjects received $40 \mathrm{~g}$ cookies three times a week for two months. The average $\mathrm{Hb}$ concentration before intervention was $13.4 \pm 1.4 \mathrm{~g} / \mathrm{dL}$. After intervention, there was an increase in hemoglobin concentration (mean $0.4 \pm 1.6 \mathrm{~g} / \mathrm{dL}$ ). About $65.2 \%$ subjects experienced increase in their $\mathrm{Hb}$ concentration. However, after the intervention the anemia prevalence slightly increased from $10.8 \%$ to $18.8 \%$ although this increase is not statistically significant $(\mathrm{p}>0.05)$. In conclusion, fortified sweet potato cookies intervention for two months does not reduce anemia prevalence in female students. Further studies are required by extending intervention times and applying other indicators of iron status. [MKB. 2013;45(4):206-12]
\end{abstract}

Key words: Anemia, cookies, fortification, schoolgirls, sweet potato Korespondensi: Dodik Briawan, Departemen Gizi Masyarakat-FEMA, Jl Lingkar Akademik Kampus IPB Dramaga, Bogor
16680. Telepon 0251-8621363 Fax. 0251-8622276, mobile 081314619119, email dbriawan@yahoo.com 


\section{Pendahuluan}

Remaja wanita merupakan salah satu kelompok yang memiliki risiko tinggi terhadap kejadian anemia. Anemia yang terjadi pada anak sekolah akan menurunkan tingkat kesehatan, prestasi akademik, dan kemampuan fisik. Analisis data Survei Kesehatan Rumah tangga (SKRT) tahun 2001 oleh Permaesih dan Herman, ${ }^{1}$ faktor risiko anemia pada remaja adalah tingkat pendidikan, jenis kelamin, usia, wilayah tempat tinggal, kebiasaan sarapan, riwayat kesehatan, dan berat badan.

Prevalensi anemia remaja wanita di Indonesia masih cukup tinggi sebesar 20-40\%. Program pemerintah untuk dapat menurunkan prevalensi anemia ternyata hasilnya kurang bermakna oleh karena prevalensi anemia yang masih cukup tinggi. Tiga strategi penanggulangan kejadian anemia di Indonesia berupa suplementasi, pendidikan gizi, serta fortifikasi pangan. ${ }^{2}$ Pemerintah Indonesia telah melaksanakan Program Pencegahan dan Penanggulangan Anemia Gizi Besi (PPAGB) dengan sasaran yaitu anak sekolah menengah (SMP dan SMA) melalui pemberian suplementasi (kapsul) zat besi.

Program PPAGB tidak selalu berhasil karena di beberapa kabupaten/kota prevalensi anemia tidak menurun. Penelitian Briawan dkk. ${ }^{2}$ di Kota Bekasi hanya menurunkan prevalensi kejadian anemia pada siswi SMP dan SMK sebesar 3,4\%. Hal tersebut disebabkan antara lain penerimaan (compliance) suplemen yang rendah.

Kebutuhan zat besi yang tinggi pada remaja wanita akan sulit dipenuhi apabila asupannya hanya berasal dari konsumsi pangan yang didapat sehari-hari. Konsumsi pangan 37,9\% masyarakat Indonesia masih di bawah 50\% kecukupan zat besi, sehingga tanpa didukung program fortifikasi, perbaikan kualitas konsumsi pangan masyarakat akan sulit dipenuhi. ${ }^{3}$

Program dan penelitian suplementasi zat besi dengan zat gizi lainnya untuk perbaikan status besi sudah banyak dilakukan. Sementara itu penelitian fortifikasi pangan, terutama yang memanfaatkan bahan pangan lokal untuk penurunan prevalensi anemia masih belum banyak dilakukan. Tujuan penelitian ini menguji efikasi fortifikasi cookies ubi jalar untuk perbaikan status besi pada siswi remaja.

\section{Metode}

Desain penelitian ini mempergunakan pre/posttest intervention study. Uji coba produk cookies dilakukan pada siswi sekolah menengah yang berlokasi di Kabupaten Bogor, yang memiliki komitmen baik dan jadwal yang sesuai dengan kegiatan penelitian. Ethical clearance penelitian diperoleh dari Fakultas Kedokteran Universitas Diponegoro dan Rumah Sakit Umum Pendidikan dr. Kariadi Semarang. Kesediaan sekolah dan partisipasi siswi sebagai subjek ditunjukkan oleh pernyataan persetujuan secara tertulis (informed consent).

Fortifikan yang digunakan untuk cookies ubi jalar adalah vitamin A, vitamin B12, vitamin $\mathrm{C}$, asam folat, dan mineral besi. Jenis dan jumlah fortifikan yang dipergunakan berdasarkan studi suplementasi besi-multivitamin oleh Briawan dkk. ${ }^{4}$ Fortifikan dalam bentuk premix dicampur dalam tepung ubi jalar dan diolah bersama-sama adonan krim. Jumlah penambahan fortifikan per 100 gram cookies adalah vitamin A (retinil asetat) $10,5 \mathrm{mg}$; vitamin $\mathrm{B}_{12}$ (sianokobalamin) $42 \mu \mathrm{g}$; vitamin C (asam askorbat) 1,25 g; asam folat 2 $\mathrm{mg}$; dan besi fumarat $150 \mathrm{mg}$.

Jumlah sampel penelitian ini yang diperlukan dengan estimasi dapat mendeteksi penurunan anemia 50\%, tingkat kepercayaan $95 \%\left(Z_{\alpha}=1,96\right)$ dan power of test $=90 \%\left(Z_{\beta}=1,28\right)$, diperlukan minimal 73 siswi per kelompok. Untuk mengatasi kemungkinan drop out, maka ditetapkan jumlah minimum sampel 75 siswi.

Sampel penelitian ini adalah siswi Sekolah Menengah Kejuruan (SMK) Pelita Kabupaten Bogor dari Jurusan Keperawatan sebanyak 41 siswi. sedangkan dari Jurusan Butik sebanyak 42 siswi. Persyaratan sampel adalah tidak sedang menderita sakit, memperoleh izin dari orangtua, dan bersedia mengikuti kegiatan sampai selesai. Dari daftar sebanyak 81 siswi kedua jurusan dalam pengambilan data awal hanya 74 orang yang hadir dan selanjutnya sebanyak 74 siswi wanita yang mengikuti program intervensi. Selama intervensi terdapat dua orang mengundurkan diri karena sakit dan dalam pengobatan serta pindah sekolah.

Intervensi cookies diberikan tiga kali dalam satu minggu dan mulai diberikan tanggal $28 \mathrm{Mei}$ sampai dengan 23 Juli 2012 (2 bulan). Cookies diberikan di sekolah oleh asisten peneliti (empat orang) setiap hari Selasa, Rabu, dan Sabtu yang diantar ke sekolah. Setiap kali distribusi, siswi memperoleh 40 gram cookies yang dibungkus dalam aluminium foil (@20 gram per bungkus), dan sedapat-dapatnya langsung dikonsumsi pada hari distribusi.

Peubah yang dikumpulkan yaitu karakteristik sampel, konsumsi pangan, alokasi pengeluaran, status kesehatan dan riwayat penyakit, ukuran antropometri, hemoglobin ( $\mathrm{Hb})$, serta konsumsi cookies. Peubah tersebut dikumpulkan melalui wawancara, pengisian kuesioner, pengukuran langsung antropometri, dan analisis laboratorium. Kepatuhan konsumsi cookies dihitung dengan 
cara siswi mengisi formulir (self reported) yang menjelaskan jumlah cookies yang dimakan dan sisanya. Kuesioner endline dikumpulkan setelah dua bulan pelaksanaan intervensi.

Untuk menghitung tingkat kecukupan energi dan zat gizi dipergunakan angka kecukupan gizi (AKG) Indonesia. Kategori tingkat konsumsi energi dan protein ialah $<70 \%$ defisit berat, $70-80 \%$ defisit sedang, $80-90 \%$ defisit ringan, 90-110\% normal, dan $>110 \%$ kelebihan. Untuk vitamin $\mathrm{A}$, vitamin $\mathrm{C}$, dan zat besi kategori tingkat konsumsi menggunakan batas $70 \%$ AKG.

Kategori anemia bila kadar $\mathrm{Hb}<12 \mathrm{~g} / \mathrm{dL}^{5}$ Penentuan status gizi antropometri menggunakan indeks massa tubuh berdasarkan usia (IMT/U). Kategori tingkat compliance konsumsi cookies adalah $<60 \%$ rendah, $60-80 \%$ sedang, dan $>80 \%$ tinggi.

Untuk uji perubahan konsumsi pangan, tingkat kecukupan zat gizi (TKG), dan kadar Hb sebelum dan setelah intervensi dipergunakan uji beda-t berpasangan (paired $t$-test). Perbedaan prevalensi anemia menggunakan Uji Wilcoxon. Analisis kovariat (ANCOVA) untuk menguji perubahan kadar $\mathrm{Hb}$, dengan memasukkan kemungkinan peubah perancu seperti pengetahuan gizi, sikap gizi, uang saku, usia, siklus menstruasi, IMT/U, $\mathrm{Hb}$ awal, serta tingkat kecukupan protein, $\mathrm{Fe}$, dan vitamin A.

\section{Hasil}

Usia rata-rata subjek adalah $16,6 \pm 0,7$ tahun, dengan rentang 14,7-18,5 tahun. Berat badan (BB) rata-rata subjek 47,9 7,4 kg (rentang 32-70 $\mathrm{kg}$ ) dan tinggi badan (TB) $152,6 \pm 4,9 \mathrm{~cm}$ (rentang
143-170 cm). Ukuran antropometri lainnya yaitu lingkar pinggang dan pinggul, berturut-turut $70,7 \pm 12,2 \mathrm{~cm}$ dan $81,9 \pm 5,8 \mathrm{~cm}$.

Indeks IMT/U rata-rata sebesar $20,5 \pm 3,2 \mathrm{~kg} /$ $\mathrm{m}^{2}$, dan kategori subjek dengan status gizi normal sebanyak $82 \%$. Terdapat satu subjek (1\%) dengan status gizi sangat kurang, dan empat subjek (5\%) gizi kurus. Di lain pihak, terdapat 6 (enam) subjek $(8 \%)$ kegemukan dan dua subjek (3\%) obes.

Semua subjek merupakan siswi remaja yang sudah mengalami menstruasi. Usia pertama kali mengalami menstruasi (menarche) berkisar 9-15 tahun (rata-rata 12,8 tahun). Sebanyak 2 subjek (3\%) sudah mengalami menstruasi sejak usia $\leq 10$ tahun.

Pada awal penelitian ini terdapat 55\% subjek menyatakan gangguan dalam kesehatan. Sesudah dilakukan intervensi terdapat peningkatan subjek yang mengalami gangguan kesehatan menjadi $69 \%$. Keluhan yang terbanyak dilaporkan adalah sakit lambung, kepala pusing, sakit tenggorokan, perut, dan batuk pilek.

Subjek semuanya mengonsumsi nasi sebagai makanan pokok, namun konsumsinya rata-rata sangat rendah (123 g/hari), dan tidak terdapat perbedaan signifikan setelah intervensi. Tahu dan tempe merupakan kacang-kacangan yang banyak dikonsumsi sebagai lauk pauk nabati. Konsumsi lauk dari nabati tersebut sebanyak $46 \mathrm{~g} / \mathrm{hari}$. Lauk hewani yang paling banyak dikonsumsi adalah daging ayam dan daging sapi. Terdapat perbedaan yang cukup besar mengenai konsumsi daging rata-rata sebelum dan setelah intervensi. Selain konsumsi daging, konsumsi telur dan ikan berbeda setelah intervensi (Tabel 1).

Konsumsi sayuran siswi juga sangat rendah, yaitu $43 \mathrm{~g} /$ hari. Konsumsi sayuran yang paling

Tabel 1 Konsumsi Pangan Rata-rata Sebelum dan Setelah Intervensi

\begin{tabular}{lccc}
\hline \multicolumn{1}{c}{ Jenis Pangan } & Sebelum $(\mathbf{g})$ & Setelah $(\mathbf{g})$ & $\mathbf{p}^{*}$ \\
\hline Serealia & 122,6 & 144,3 & 0,052 \\
Kacang-kacangan & 45,8 & 57,7 & 0,073 \\
Daging (ayam, sapi, dan kambing) & 77,9 & 165,1 & 0,219 \\
Telur & 50,0 & 56,7 & 0,040 \\
Ikan (termasuk kerang dan udang) & 58,3 & 70,6 & 0,061 \\
Sayuran & 43,3 & 19,7 & 0,228 \\
Buah-buahan & 73,4 & 54,4 & 0,094 \\
Susu (siap minum) & 112,0 & 90,0 & 0,069 \\
Minuman kemasan & 493,0 & 217,7 & 0,235 \\
Makanan kemasan & 38,8 & 24,5 & 0,141 \\
Makanan sepinggan & 321,0 & 157,3 & 0,210 \\
\hline
\end{tabular}

Keterangan: *paired t-test 
Dodik Briawan: Efikasi Fortifikasi Cookies Ubi Jalar untuk Perbaikan Status Anemia Siswi Sekolah

Tabel 2 Asupan dan Tingkat Kecukupan Gizi Sebelum dan Setelah Intervensi

\begin{tabular}{lccccc}
\hline \multirow{2}{*}{ Zat Gizi } & \multicolumn{2}{c}{ Sebelum } & \multicolumn{2}{c}{ Setelah } & \multirow{2}{*}{ p } \\
\cline { 2 - 5 } & Asupan & \% TKG & Asupan & \% TKG & \\
\hline Energi (kkal) & $987 \pm 416$ & $44,9 \pm 18,9$ & $776 \pm 347$ & $38,8 \pm 17,3$ & 0,000 \\
Protein (g) & $37,6 \pm 19,4$ & $75,3 \pm 38,8$ & $28,2 \pm 16,2$ & $55,3 \pm 31,8$ & 0,000 \\
Fe (mg) & $9,9 \pm 5,1$ & $38,1 \pm 19,7$ & $9,9 \pm 10,1$ & $39,6 \pm 40,3$ & 0,000 \\
Vit C (mg) & $25 \pm 26$ & $32,8 \pm 34,6$ & $24 \pm 80$ & $40,7 \pm 133,5$ & 0,000 \\
Vit A (RE) & $552 \pm 652$ & $91,9 \pm 108,7$ & $439 \pm 567$ & $87,8 \pm 113,5$ & 0,000 \\
\hline
\end{tabular}

banyak adalah sop sayuran, sop wortel serta kentang, tumis kangkung, sayuran bayam, tumis labu, urap sayuran, dan sayuran sawi. Setelah intervensi terjadi penurunan konsumsi sayuran. Konsumsi buah-buahan relatif lebih banyak dibandingkan dengan konsumsi sayuran (Tabel 1)

Konsumsi susu diukur dari susu siap minum, baik yang dipersiapkan sendiri (susu bubuk, susu kental manis) maupun ultra high temperature (UHT). Sebelum intervensi, konsumsi makanan snack dalam kemasan sebanyak 39 gram/hari dan menurun sesudah intervensi. Jenis makanan kemasan yang banyak dikonsumsi adalah chitatos, geri chocolato, keripik kentang, momogi, biskuat, ciki steak \& ciki singkong balado, energen sereal, oreo, astor, potato, dan sosis. Makanan sepinggan yang banyak dikonsumsi siswi adalah mie ayam, pempek, bakso, batagor, dan siomay; dan terjadi penurunan makanan sepinggan setelah intervensi.

Pada penilaian konsumsi pangan berikut tidak termasuk konsumsi cookies. Hasilnya terdapat perbedaan asupan zat gizi sebelum dengan setelah intervensi. Asupan zat gizi setelah intervensi justru tidak lebih baik dibandingkan dengan sebelum intervensi. Penurunan asupan gizi tersebut terjadi karena penurunan jumlah konsumsi pangan jenis sayur, buah, susu, makanan dan minuman kemasan, serta jenis makanan sepinggan. Tingkat kecukupan gizi energi serta protein sebelum intervensi lebih tinggi bila dibandingkan dengan setelah intervensi $(\mathrm{p}<0,05)$. Tingkat kecukupan zat gizi mikro seperti Fe dan vitamin $\mathrm{C}$ setelah intervensi lebih tinggi bila dibandingkan dengan sebelum intervensi $(\mathrm{p}<0,05$; Tabel 2$)$.

Selama delapan minggu pemberian cookies, dari 40 g cookies yang didistribusikan konsumsi cookies rata-rata sebesar $38,8 \pm 1,8 \mathrm{~g} /$ hari dengan selang 32,5-40,0 g/hari (Tabel 3). Kepatuhan

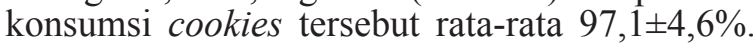
Hanya sebagian kecil cookies yang tidak dimakan dengan alasan lupa, sudah kenyang, cookies jatuh, atau dibagi dengan anggota keluarga lainnya. Estimasi total asupan zat gizi dari penjumlahan makanan rumah dan juga konsumsi cookies, menunjukkan bahwa asupan energi masih kurang; namun untuk protein, vitamin $\mathrm{A}$, vitamin $\mathrm{C}$, dan zat besi sudah memenuhi kecukupan gizi (AKG).

$\mathrm{Kadar} \mathrm{Hb}$ rata-rata sebelum intervensi adalah $13,4 \pm 1,40 \mathrm{~g} / \mathrm{dL}$ (Tabel 4). Hanya terdapat sedikit peningkatan kadar $\mathrm{Hb}$ setelah intervensi, namun

Tabel 3 Suplai Cookies, Kepatuhan, dan Estimasi Total Asupan Zat Gizi

\begin{tabular}{lccc}
\hline \multicolumn{1}{c}{ Zat Gizi } & $\begin{array}{c}\text { Suplai } \\
\mathbf{( 4 0 , 0} \mathbf{g})\end{array}$ & $\begin{array}{c}\text { Kepatuhan } \\
\mathbf{( 3 8 , 8} \mathbf{g})\end{array}$ & Estimasi Total Asupan \\
\hline Energi (kkal) & 162 & 157 & 933 \\
Lemak $(\mathrm{g})$ & 2,1 & 2,0 & - \\
Protein $(\mathrm{g})$ & 30,0 & 29,1 & 66,6 \\
Karbohidrat $(\mathrm{g})$ & 6,0 & 5,8 & - \\
Vit A ( $\mu \mathrm{g})$ & 4212 & 4086 & 4525 \\
Vit B12 $(\mu \mathrm{g})$ & 1,1 & 1,0 & - \\
Vit C $(\mathrm{mg})$ & 99,6 & 96,6 & 120,6 \\
Folat $(\mu \mathrm{g})$ & 325,7 & 315,9 & - \\
Besi $(\mathrm{mg})$ & 38,0 & 36,8 & 46,7 \\
\hline
\end{tabular}

Keterangan: -=tidak terdapat data asupan zat gizi tersebut 
Dodik Briawan: Efikasi Fortifikasi Cookies Ubi Jalar untuk Perbaikan Status Anemia Siswi Sekolah

Tabel 4 Kadar Hemoglobin dan Prevalensi Anemia Sebelum dan Setelah Intervensi

\begin{tabular}{cccc}
\hline Indikator & Sebelum & Setelah & p \\
\hline $\mathrm{Hb}(\mathrm{g} / \mathrm{dL})$ rata-rata & $13,4 \pm 1,4$ & $13,8 \pm 1,7$ & $0,040^{*}$ \\
Prevalensi anemia: & & & $0,083^{* *}$ \\
$\mathrm{Hb}<12 \mathrm{~g} / \mathrm{dL}$ & $8(11 \%)$ & $13(19 \%)$ & \\
$\mathrm{Hb} \geq 12 \mathrm{~g} / \mathrm{dL}$ & $66(89 \%)$ & $56(81 \%)$ & \\
\hline
\end{tabular}

Keterangan: *paired $t$-test, ${ }^{* *} \mathrm{Uji}$ Wilcoxon

secara statistik berbeda nyata $(\mathrm{p}<0,05)$. Terjadi peningkatan prevalensi anemia sesudah intervensi, namun secara statistik perbedaan tersebut tidak signifikan $(\mathrm{p}>0,05)$. Dari delapan subjek yang menderita anemia tersebut, setelah intervensi sebanyak $7 / 8$ subjek terjadi peningkatan kadar $\mathrm{Hb}$. Subjek penderita anemia tersebut berada pada kategori status gizi antropometri yang normal.

Analisis lebih lanjut terhadap faktor yang bepengaruh pada perubahan kadar $\mathrm{Hb}$ yaitu uji ANCOVA dengan kovariat pengetahuan gizi, sikap gizi, uang saku, usia, siklus menstruasi, IMT, Hb awal, tingkat kecukupan protein, Fe, serta vitamin $\mathrm{C}$ dan A. Peubah yang signifikan berpengaruh pada perubahan kadar $\mathrm{Hb}$ adalah nilai $\mathrm{Hb}$ awal $(\mathrm{OR}=0,42 ; 95 \% \mathrm{IK}: 0,12-0,73)$ dan siklus menstruasi (OR=0,04; 95\% IK:0,00-0,08).

\section{Pembahasan}

Ukuran berat dan tinggi badan rata-rata remaja wanita Indonesia adalah $50 \mathrm{~kg}$ dan $154 \mathrm{~cm}$. Jumlah subjek yang ukuran berat dan tinggi badannya di bawah rata-rata nasional tersebut, yaitu berturutturut $66,7 \%$ dan $61,3 \%$. Berdasarkan rasio lingkar pinggang dan panggul rata-rata subjek sebesar $0,86 \pm 0,14(0,73-1,99)$. Rasio lingkar pinggangpinggul subjek tersebut masih di bawah kriteria risiko sindrom metabolik $<0,90$.

Usia pertama kali menstruasi rata-rata subjek adalah 12,8 tahun dan usia ini relatif sama dengan penelitian di Jakarta dan Tangerang, sebanyak 12,2 tahun. ${ }^{6}$ Menstruasi yang teratur jika remaja mengalami menstruasi sesuai dengan siklusnya (25-35 hari). Jumlah subjek yang mengalami menstruasi tidak teratur sebanyak $53 \%$. Lama siklus menstruasi rata-rata subjek $28,1 \pm 3,7$ hari dan beberapa di antaranya mengalami menstruasi tidak teratur dengan rentang yang cukup lebar (0-90 hari).

Terdapat lima orang subjek (7\%) yang sedang melakukan diet untuk menurunkan berat badan atau menghindari kegemukan. Dari lima siswi yang melakukan diet tersebut ternyata hanya satu orang yang kegemukan, sedangkan empat lainnya berstatus normal. Studi lainnya di Bogor memperlihatkan bahwa remaja yang melakukan diet penurunan berat badan, yaitu 10,7\% laki-laki dan $32,0 \%$ wanita lebih besar daripada jumlah remaja dengan kategori gemuk, yaitu berturutturut $7 \%$ dan $8 \%$. $^{7}$ Sebanyak $30 \%$ remaja yang menginginkan tubuh mereka ideal melakukannya dengan cara sengaja melewatkan waktu makan, baik makan pagi, siang, atau malam. ${ }^{8}$ Terdapat kecenderungan pada remaja wanita, meskipun tidak kegemukan, tetapi mereka melakukan diet sehingga asupan energi dan protein rata-rata menjadi rendah.

Kualitas konsumsi pangan subjek penelitian ternyata masih rendah jika dibandingkan dengan rekomendasi Pedoman Umum Gizi Seimbang $\left(\right.$ PUGS $^{3}$ (Tabel 1). Dengan rekomendasikonsumsi nasi $500 \mathrm{~g}$ /hari (5 porsi), artinya konsumsi subjek ini baru mencapai 25\%. Rekomendasi konsumsi lauk nabati $150 \mathrm{~g} /$ hari (3 porsi), maka konsumsi buah tersebut rata-rata baru mencapai sebanyak $30 \%$. Konsumsi lauk nabati hanya sebesar 45,8 $\mathrm{g}$, yaitu hanya setara dengan satu potong tempe berukuran sedang. Namun demikian, konsumsi pangan hewani subjek berupa daging, telur, dan ikan sebesar 186,2 g sudah mendekati anjuran 150 $\mathrm{g} /$ hari (3 porsi). Setelah intervensi, pangan jenis serealia, lauk nabati, dan lauk hewani (daging, telur, dan ikan) terdapat sedikit peningkatan.

Anjuran konsumsi sayuran dan buah untuk kelompok remaja sebesar $300 \mathrm{~g} /$ hari (3 porsi) dan $200 \mathrm{~g} /$ hari (4 porsi) ${ }^{3}$. Konsumsi sayuran dan buah rata-rata subjek baru mencapai 15-35\%. Buah yang banyak dikonsumsi subjek adalah pisang, pepaya, apel, dan jambu biji. Setelah intervensi, konsumsi jenis sayuran dan buah-buahan justru mengalami penurunan. Demikian pula konsumsi makanan jajanan subjek juga mengalami sedikit penurunan karena substitusi cookies intervensi. Edukasi gizi selama intervensi tampaknya belum mengubah kebiasaan konsumsi pangan siswi.

Berdasarkan konsumsi pangan di atas, asupan zat gizi makro (energi dan protein), maupun zat gizi mikro (vitamin dan zat besi) subjek masih rendah bila dibandingkan dengan standar AKG. Sebelum intervensi asupan zat besi subjek hanya 
$9,9 \pm 5,1 \mathrm{mg} / \mathrm{hari}$, artinya asupan tersebut hanya menyumbang sekitar 38-40\% AKG besi. Studi terhadap mahasiswi di Bogor juga menunjukkan rendahnya asupan zat gizi mikro. Proporsi subjek yang mengalami defisit asupan vitamin dan zat besi cukup tinggi, yaitu untuk vitamin $\mathrm{A}$ dan $\mathrm{C}$ (40-70\%), sedangkan zat besi $85 \%{ }^{4}$

Asupan gizi dari konsumsi pangan harian hanya mencukupi $30-70 \%$ AKG baik sebelum dan juga setelah intervensi. Dengan pemberian cookies, estimasi total asupan zat gizi sudah mencukupi standar AKG subjek, kecuali asupan energi.

Secara subjektif siswi mampu menyebutkan gejala-gejala anemia seperti lemas, lelah, mata berkunang, cepat lesu, dan sering pingsan selama satu bulan sebelum intervensi. Sebanyak 34-42\% subjek merasa cepat lemas dan lelah, sedangkan $15 \%$ mengeluh mata berkunang-kunang. Setelah intervensi, terdapat penurunan gejala anemia, terutama siswi yang cepat lelah menurun dari $42 \%$ menjadi $32 \%$; cepat lesu dari $22 \%$ menjadi $17 \%$. Studi sebelumnya dengan intervensi kapsul multivitamin, secara subjektif terdapat manfaat yang dirasakan setelah 1-3 hari minum kapsul. Manfaat yang paling banyak dirasakan yaitu fisik menjadi tidak mudah lelah dan jarang sakit. ${ }^{4}$ Studi eksperimental pada wanita tidak anemia namun kadar feritin serum rendah, dengan perlakuan suplemen besi fero-sulfat selama 12 minggu menunjukkan penurunan skor kelelahan sebesar $48 \%$ dibandingkan dengan kelompok plasebo yang menurun $29 \%{ }^{9}$

Perubahan kadar $\mathrm{Hb}$ rata-rata selama periode intervensi $0,4 \pm 1,6 \mathrm{~g} / \mathrm{dL}$ dengan selang antara $-3,8$ sampai $3,5 \mathrm{~g} / \mathrm{dL}$. Artinya, terdapat siswi yang selama intervensi mengalami peningkatan kadar $\mathrm{Hb}$ dan beberapa siswi terjadi penurunan $\mathrm{Hb}$. Setelah dilakukan intervensi, sebanyak $65 \%$ subjek mengalami kenaikan $\mathrm{Hb} ; 32 \%$ subjek mengalami penurunan $\mathrm{Hb}$; dan 3\% kadar $\mathrm{Hb}$ tidak mengalami perubahan. Studi di Afrika Selatan dengan intervensi fortifikasi roti tawar pada anak sekolah 4 potong per hari $(2,35-8,30 \mathrm{mg} \mathrm{Fe} / \mathrm{hari})$ selama 34 minggu tidak menunjukkan perubahan kadar $\mathrm{Hb}$ dan biomarker status besi lainnya. ${ }^{10}$ Demikian pula fortifikasi nasi untuk makan siang anak sekolah di Thailand selama 5 bulan, tidak menunjukkan perubahan kadar $\mathrm{Hb} .{ }^{11}$ Namun, peningkatan $\mathrm{Hb}$ subjek penelitian ini masih lebih rendah dibandingkan dengan studi eksperimental yang menmpergunakan suplementasi besi, yaitu $0,08-1,12 \mathrm{~g} / \mathrm{dL} .{ }^{6,9,12}$

Evaluasi program suplementasi besi para siswi SMP dan SMK di Kota Bekasi memperlihatkan perbaikan status anemia. Kadar $\mathrm{Hb}$ rata-rata sebelum suplementasi $12,4 \mathrm{~g} / \mathrm{dL}$ dan setelah itu menurun menjadi $12,3 \mathrm{~g} / \mathrm{dL}$. Setelah program suplementasi, tidak terdapat perubahan prevalensi anemia dan masih terdapat $22 \%$ siswi yang tetap anemia. $^{2}$

Intervensi fortifikasi cookies multigizi dua kali per minggu selama delapan minggu meningkatkan kadar $\mathrm{Hb}$ secara signifikan, namun belum dapat menurunkan prevalensi anemia. Peubah yang signifikan berpengaruh pada perubahan kadar $\mathrm{Hb}$ subjek adalah nilai $\mathrm{Hb}$ awal $(\mathrm{OR}=0,42 ; 95 \% \mathrm{IK}$ : $0,12-0,73)$ dan siklus menstruasi (OR $=0,04 ; 95 \%$ IK:0,00-0,08). Setelah intervensi, kemungkinan subjek yang sebelumnya tidak anemia dan siklus menstruasi lebih lama menjadi tidak menderita anemia dengan peluang sebesar $0,42 \%$ dan $0,04 \%$.

Studi eksperimental mengenai suplementasi besi menunjukkan bahwa perubahan kadar $\mathrm{Hb}$ hanya dipengaruhi oleh $\mathrm{Hb}$ awal. Analisis dengan memasukkan peubah perancu, seperti serum ferritin (SF), serum transferrin receptor (STfR), $\mathrm{Hb}$, IMT, kepatuhan, \% AKG energi, protein, vitamin $\mathrm{A}$, vitamin $\mathrm{C}$, zat besi tidak berpengaruh signifikan pada perubahan $\mathrm{Hb}^{4}{ }^{4}$ Pada kebanyakan studi eksperimental yang lainnya, status besi awal berpengaruh pada perubahan nilai hemoglobin dan feritin serum. ${ }^{6,12,13}$

Pada penelitian ini fortifikasi cookies hanya sedikit meningkatkan kadar $\mathrm{Hb}$ siswi remaja. Hal ini kemungkinan disebabkan karena retensi vitamin fortifikan di dalam proses pembuatan cookies yang ternyata rendah, sehingga dosis tidak sesuai dengan desain awal. Selain itu, dapat disebabkan karena lama intervensi yang singkat (dua bulan), sehingga dampaknya pada kadar $\mathrm{Hb}$ belum terlihat signifikan. Menurut Davidson dan Nestel, ${ }^{13}$ kemungkinan kegagalan pembuktian studi efikasi suplementasi dan fortifikasi besi di antaranya tidak mencukupinya dosis zat besi, tingkat kepatuhan, jangka waktu intervensi yang singkat, periode kebutuhan zat gizi sangat tinggi, defisit zat gizi lainnya baik mikro dan makro, serta status gizi sebelum intervensi yang rendah.

Terdapat tiga tahapan defisiensi besi di dalam tubuh, yaitu berturut-turut deplesi simpanan zat besi, defisiensi besi eritropoesis, dan defisiensi besi anemia. Pada penelitian ini, penilaian status besi dilaksanakan pada tahap akhir terjadinya defisiensi zat besi yang disebut anemia. Dengan indikator $\mathrm{Hb}$, tidak dapat dijelaskan penyebab anemia oleh karena defisit gizi besi atau infeksi ${ }^{5,14}$ sehingga kemungkinan siswi yang mengalami infeksi/inflamasi dapat mengakibatkan kadar hemoglobin menurun dan tidak terdeteksi.

Penelitian efikasi fortifikasi cookies diperlukan lebih lanjut terutama peningkatan frekuensi atau durasi pemberiannya. Selain itu, perlu digunakan indikator status besi yang lebih sensitif seperti STfR dan SF untuk menggambarkan distribusi 
besi dalam tubuh. Penggunaan $\mathrm{Hb}$, STfR, dan SF sebagai kombinasi pengukuran status besi di dalam tubuh merupakan indikator terbaik untuk pengukuran status besi. ${ }^{14,15}$ Simpulan, intervensi fortifikasi cookies ubi jalar selama 2 (dua) bulan tidak menurunkan prevalensi anemia pada anak sekolah. Disarankan menambah waktu intervensi dan menggunakan indikator status besi pada penelitian lainnya.

\section{Daftar Pustaka}

1. Permaesih D, Herman S. Faktor-faktor yang mempengaruhi anemia pada remaja. Buletin Penelitian Kesehatan. 2005;33:162-71.

2. Briawan D, Adriani A, Pusporini. Determinan keberhasilan program suplementasi zat besi pada remaja putri (siswi SMP dan SMK) di Kota Bekasi, Jurnal Gizi Klinik Indonesia. 2009;6(2):78-83.

3. Departemen Kesehatan. Pedoman Umum Gizi Seimbang (PUGS). Jakarta: Depkes RI; 2005.

4. Briawan D, Hardinsyah, Setiawan B, Marliyati SA, Muhilal. Efikasi suplemen besi-multivitamin untuk perbaikan status besi remaja wanita. Jurnal Gizi Indonesia. 2008;30(1):30-6.

5. Ahmed F, Khan MR, Akhtaruzzaman M, Karim R, Williams G, Torlesse H, dkk. Longterm intermittent multiple micronutrient supplementation enhances hemoglobin and micronutrient status more than iron+folic acid supplementation in Bangladeshi rural adolescent girls with nutritional anemia. J Nutr. 2010;140:1879-86.

6. Dillon DHS. Nutritional health of Indonesian adolescent girls: the role of riboflavin and vitamin A on iron status [Thesis]. Netherlands: Wageningen University; 2005.

7. Briawan D, Harahap $\mathrm{H}$, Martianto $\mathrm{M}$. Hubungan konsumsi pangan dan status gizi dengan body image pada remaja di perkotaan.
Jurnal Gizi Indonesia. 2008;30(2):51-6.

8. Septiadewi D, Briawan D. Penggunaan metode body shape questionnaire (BSQ) dan figure rating scale (FRS) untuk pengukuran persepsi tubuh remaja wanita. Jurnal Gizi Indonesia. 2010;33(1):29-36.

9. Voucher P, Druais P, Waldvogel S, Favrat B. Effect of iron supplementation on fatigue in nonanemic menstruating women with low ferritin: a randomized control trial. Canadian Medical Association. 2012;184(11):1247-54.

10. van Stuijvenberg ME, Smuts CM, Lombard CJ, Dhansay MA. Fortifying brown bread with sodium iron EDTA, ferrous fumarate, or electrolytic iron does not affect iron status in South African schoolchildren. J Nutr. 2008;138:782-6.

11. Pinkaew S,Winichagoon $P$, Hurrell RF, Wegmuller R. Extruded rice grains fortified with zinc, iron, and vitamin A increase zinc status of Thai school children when incorporated into a school lunch program. J. Nutr. 2013. doi: 10.3945/jn.112.166058.

12. Ahmed F, Khan MR, Akhtaruzzaman M, Karim R, Marks GC, Banu CP, dkk. Efficacy of twice weekly multiple micronutrient supplementation for improving the hemoglobin and micronutrient status of anemia adolescent schoolgirls in Bangladesh. Am J Clin Nutr. 2005;82:829-35.

13. Davidson L, Nestel P. Efficacy and effectiveness of intervention to control iron deficiency and iron deficiency anemia. Washington DC: INACG; 2004.

14. Mei Z, Cogswell ME, Parvanta I, Lynch S, Beard JL, Stoltzfus RJ dkk. Hemoglobin and ferritin are currently the most efficient indicators of population response to iron intervention: an anlysis of nine randomized controlled trials. J Nutr. 2005;135:1974-80.

15. Walsh T, O’Broin SD, Cooley S, Donnelly J, Kennedy J, Harrison RF, dkk. Laboratory assessment of iron status in pregnancy. Clin Chem Lab Med. 2011;49(7):1225-30. 